\section{Gamma Radiation Unpromising as an Insect Quarantine Treatment for Fraser Fir Branches}

\author{
L. Eric Hinesley ${ }^{1}$ and Layne K. Snelling ${ }^{2}$ \\ Department of Horticultural Science, North Carolina State University, Raleigh, \\ NC 27695-7609
}

Additional index words. Christmas trees, Abies fraseri, irradiation, postharvest quality

\begin{abstract}
Dormant branches of Fraser fir [Abies fraseri (Pursh) Poir.] Christmas trees were subjected to single doses of gamma radiation at levels ranging from 0 to $5.0 \mathrm{kGy}(0$ to 500 kRad). Significant needle loss resulted at doses $\geq 0.10 \mathrm{kGy}$ and increased with radiation intensity. Irradiation discolored foliage and accelerated drying. Irradiation does not appear to be a viable way to meet insect quarantine requirements on cut Fraser fir Christmas trees.
\end{abstract}

About 36 million live Christmas trees are sold annually in the United States (Baumann, 1992), and growth in the international market is also increasing. Live Christmas trees harbor insect pests, and disinfestation procedures will be required to meet import regulations of foreign markets.

Fraser fir is an important Christmas tree species in North America, and since it will be exported in greater quantity in the future, information is needed on quarantine treatments. Fraser fir is relatively tolerant of methyl bromide (G.A. Chastagner et al., unpublished data; U.S. Dept. of Agriculture, 1977), but information concerning its response to radiation is lacking.

Since balsam fir (Abies balsamea L.), a closely related species, is relatively sensitive to chronic, low-level doses of gamma radiation (Dugle, 1986), we examined postharvest quality of gamma-irradiated Fraser fir branches.

High radiation doses (Expt. 1). Ten uniform branches were collected from the middle crown of each of eight Fraser fir trees (height, $\approx 2 \mathrm{~m}$; age, $\approx 12$ years) at Waynesville, N.C., on 10 Nov. 1992 and stored in buckets of water. About $1 \mathrm{~h}$ later, branches from each tree were cut to a length of $\approx 0.5 \mathrm{~m}$ and tied together in pairs. One pair from each tree was placed in each of five small corrugated boxes, which were then packaged in a larger box and sent, overnight, to a commercial ${ }^{60} \mathrm{Co}$ food irradiation facility in Florida. The next day, each box

\footnotetext{
Received for publication 18 Feb. 1993. Accepted for publication 30 June 1993. This research was funded by the North Carolina Agricultural Research Service (NCARS), Raleigh. Use of trade names in this publication does not imply endorsement by the NCARS of products named nor criticism of similar ones not mentioned. We thank Bill Hargraves and Ed Sullivan (Vindicator Corp., Plant City, Fla.) for cooperating in this work. The cost of publishing this paper was defrayed in part by the payment of page charges. Under postal regulations, this paper therefore must be hereby marked advertisement solely to indicate this fact.

'Professor.

${ }^{2}$ Research Technician.
}

was randomly assigned to one of five target (0 to $500 \mathrm{kRad})$. Actual radiation levels, based on dosimeters (GammaChrome Laboratories, England), were 0, 0.64, 1.19, 2.54, and 4.64 $\mathrm{kGy}$, and the rate of irradiation was $\approx 0.26$ $\mathrm{kGy} \cdot \mathrm{min}^{-1}$. Each box had several vent holes for gas exchange. After irradiation, boxes were returned, overnight, to Raleigh.

On 12 Nov. 1992, branches were setup in a laboratoty at Raleigh. One branch from each pair and each treatment was placed in a flask of distilled water (butt end down); the other was displayed dry. Temperature and relative humidity were $18 \pm 3 \mathrm{C}$ and $40 \% \pm 10 \%$, respectively. Branches received fluorescent lighting (0800 to $1700 \mathrm{HR}$ ) on most weekdays.

After 2 weeks, needle loss was determined by lightly rubbing each shoot between the thumb and forefinger. Abscised needles were dried for 3 days at $65 \mathrm{C}$ and weighed. Residual foliage on each branch was dried similarly and weighed. Needle loss was calculated as a percentage of the total foliage weight on each branch. Foliage color was evaluated with Munsell color charts (Kollmorgen Corp., 1977).

Low radiation doses (Expt. 2). Six additional branches were collected from the middle crown of the same trees on 1 Dec. 1992. They were paired and packaged as in Expt. 1. Irradiation levels of $0,0.1$, and $0.34 \mathrm{kGy}$ were administered (rate $=0.01 \mathrm{kGy} \cdot \mathrm{min}^{-1}$ ) on $2 \mathrm{Dec}$. 1992. Branches were set upon 3 Dec. 1992 and observed for 2 weeks. Again, one branch of each pair was displayed wet; the other was dry. Needle loss and color was recorded after 2 weeks.

In the first experiment, most branches, whether held wet or dry, that received 4.64 kGy showed heavy needle drop less than $24 \mathrm{~h}$ after irradiation (data not presented), as did some that received $2.5 \mathrm{kGy}$. Dry branches subjected to $0.64 \mathrm{kGy}$ lost few needles, whereas $1.2 \mathrm{kGy}$ induced $\approx 35 \%$ needle abscission (Fig. 1A). Most needle abscission on dry branches occurred during the first few days after treatment. Treated branches dried rapidly and became brittle, indicating death. Nonirradiated doses of radiation: $0,0.5,1.0,2.5$, and $5.0 \mathrm{kGy}$ branches displayed in water lost few needles (Fig. 1B). Needle loss of wet branches was $46 \%$ at $0.64 \mathrm{kGy}$ and increased at higher dosages (Fig. 1B).

Needles on all treatments (wet and dry), except nonirradiated controls, turned a bronzegreen (Munsell colors: $5 \mathrm{Y} 4 / 4$ or $5 / 4 ; 2.5 \mathrm{GY}$ $5 / 2$ or $5 / 4$ ) within 2 to 3 days. After 2 weeks, nonirradiated branches were in excellent condition, needle loss was negligible, and color was dark green (Munsell colors: 7.5GY 3/4 or 4/4). However, several dry, nonirradiated branches were somewhat lighter in color (Munsell colors: $5 \mathrm{GY} 4 / 6$ or $4 / 8$ ).

In the second experiment, wet branches subjected to $0.34 \mathrm{kGy}$ had $100 \%$ needle loss during the 2-week display period (Fig. 1B). Comparable dry branches lost only 5\% of their needles, but foliage discolored severely. Branches subjected to $0.1 \mathrm{kGy}$, and displayed in water, lost $42 \%$ of their needles, but the remaining foliage had good color. As in Expt. 1, nonirradiated branches were in excellent condition after 2 weeks.

Our results indicate that Fraser fir is sensitive to gamma radiation, much like its close relative, balsam fir (Dugle, 1986). Branches subjected to single doses as low as $0.1 \mathrm{kGy}$ averaged $40 \%$ needle loss when displayed in water (Fig. 1B). However, there was great intertree variation, e.g., within the $0.1-\mathrm{kGy}$ treatment, needle loss ranged from $5 \%$ to $100 \%$ among wet branches. The cumulative
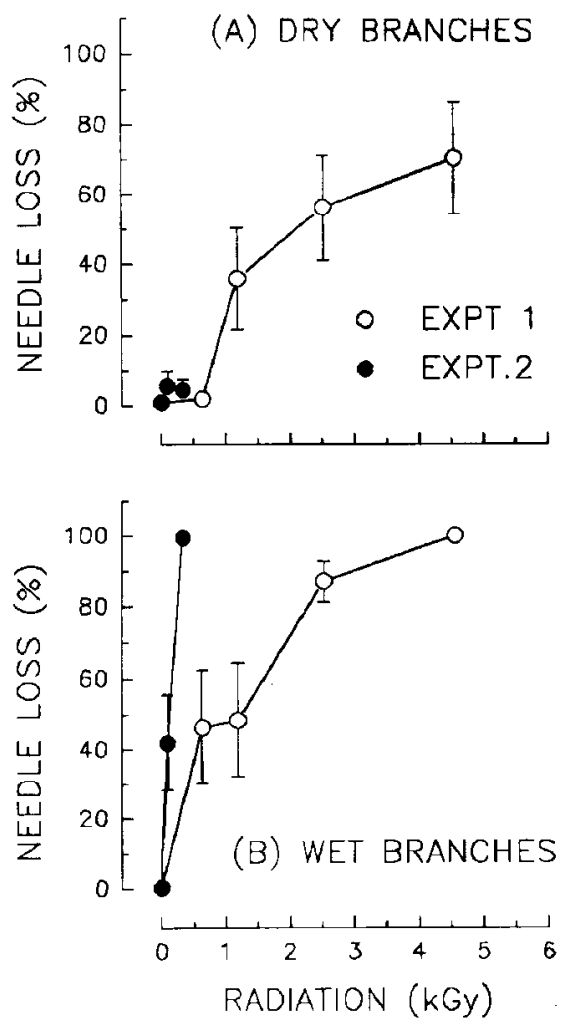

Fig. 1. Needle abscission (percent dry-weight basis) on dormant branches of Fraser fir $(n=8)$ following single doses of gamma radiation. (A) Branches displayed for 2 weeks without water or (B) with water. Expt. $1(O)$; Expt. 2 (O). Vertical bars \pm sE. 
lethal dose $\left(\mathrm{LD}_{50}\right)$ is $\approx 0.1 \mathrm{kGy}$ for balsam fir subjected to low-level gamma radiation (Dugle, 1986). Although applied over a period of years, this $\mathrm{LD}_{50}$ is similar to the lowest radiation level in our experiments.

We cannot explain the disparity between the $0.64-\mathrm{kGy}$ treatment (45\% needle drop) in Expt. 1 and the 0.34-kGy treatment $(100 \%$ needle drop) in Expt.2 (Fig. 1B). The rate of irradiation was possibly a contributing factor. Evidently, 0.34 kGy caused extensive damage but was not severe enough to kill the foliage and other tissues quickly. Consequently, branches held in water remained alive long enough for all foliage to abscise completely.

Sterilizing insect pests in cut Christmas trees would probably require 0.5 to $1.0 \mathrm{kGy}$ (Tilton and Burditt, 1983), and levels needed to kill insects outright would be higher. Fraser fir appears to be intolerant of that much radiation (Fig. 1), and a single dose of gamma radiation is not a viable way to sterilize or kill insect pests on cut Fraser fir Christmas trees.

\section{Literature Cited}

Baumann, D. 1992. 1992 NCTA/Gallop Poll results-Part 1: Real tree safes up slightly despite sour economy. Amer. Christmas Tree J. 36(2):26-27.

Dugle, J.R. 1986. Growth and morphology in balsam fir: Effects of gamma radiation. Can. J. Bot. 64:1484-1492.

Kollmorgen Corp. 1977. Munsell color chart for plant tissues. 2nd ed. Baltimore, Md.

Tilton, E.W. and A.K. Burditt, Jr. 1983. Insect disinfestation of grain and fruit, p.215-229. In E.S. Josephson and M.S. Peterson (eds.). Preservation of foods by ionizing radiation. vol. 3 . CRC Press, Boca Raton, Fla.

U.S. Dept. of Agriculture. 1977. Handbook of plant tolerances to methyl bromide. Animal and Plant Health Inspection Serv., Hoboken, N.J. 